\title{
The Revival of Ancient Hebrew Words With the Revival of Israel
}

\author{
Bat-Zion Yemini \\ Levinsky College, Tel Aviv, Israel
}

\begin{abstract}
In this study, all the words in the latest edition of the Hebrew Even Shoshan Dictionary (2003) were scanned and ancient words that were not used continuously throughout the Hebrew strata — used in Modern Hebrew in their old or new meaning - were collected. After finding the appropriate words, we examined their incidence in the Gur dictionary (1946) to ensure that the new meanings had not existed then. We have determined the scope of usage by general knowledge and Google Search. The 99 ancient words with new meanings were identified, 39 of which are foreign, according to this distribution: 31 biblical words, 44 words of the Sages, and 24 medieval words. In parallel with the 70 years of Israel's independence, many ancient words were reintroduced with new modern meanings, to answer the need to create terms for the institutions of the sovereign state and for the masses of Jewish immigrants who spoke foreign languages. Most of the words are from the Mishnah period, the last period in which Hebrew was a living language and adopted foreign words from the developed and advanced cultures of its day. The article presents the innovations of words in different fields, explains it, and answers another questions.
\end{abstract}

Keywords: revival of Hebrew words, revival of Israel, ancient words, loanwords, neologisms

\section{The Revival of the Hebrew Language}

This article presents the results of research into the revival of ancient Hebrew words in Modern Hebrew, in the 70 years from the establishment of the State in 1948 through 2018.

First, we discuss the revival of the Hebrew language itself, a phenomenon without parallel in the history of languages or peoples. Bar-Asher (2002) distinguished between the revival of Hebrew literature approximately 270 ago in the Age of the Enlightenment, when Hebrew works spread across Europe, and the revival of spoken Hebrew starting in 1881, in the wake of Eliezer Ben-Yehuda's immigration to the Land of Israel. Cohen (2005) described Biblical Hebrew as a linguistic paragon for the generations preceding the Enlightenment, and argued that this norm was later changed by Mendele Mocher Sforim, who incorporated all registers of the language into his work, paving the way for numerous other writers who adopted his literary style. Nonetheless, some purists took pains to base the grammar of Modern Hebrew on Biblical Hebrew. This canon, however, gradually eroded with the growing perception that the "correct" use of Hebrew need not exclude post-Biblical registers. Since Hebrew was reinstated as the primary spoken language of the Jews, the Hebrew Language Committee strove to base its linguistic decisions and innovations on all its registers, and the committee's current incarnation, the Academy of the Hebrew Language, has continued that tradition. In his article entitled "Numerous Achievements and a Few Failures in One Hundred Years of Shaping the Hebrew Language" (1991), Yannai surveys the

Bat-Zion Yemini, Ph.D., senior lecturer, Hebrew Linguistics Department, Levinsky College, Tel Aviv, Israel. 
endeavor of planning the language. He explains that one of the aims of its revival relates to sociolinguistics, namely, to stamp out the rift and hostility that existed at the beginning of the 20th century between Sefardi and Ashkenazi Jews, and to help fashion a united society in Israel based on brotherhood and unity.

Morag (1990) divided the timeframe of the revival of Hebrew as a spoken language into three sub-periods, aligned with the Zionist endeavor of immigration and settlement: The first is between 1882 and 1918, encompassing the First World War; the second ends with the establishment of the State in 1948; and the third continues to the present day. The beginning of the third period is marked by waves of mass immigration that brought with them speakers of many different languages. Although these immigrants found a broad and solid foundation of Hebrew, their influence on the vernacular was extensive: In 1948, 75\% of the population spoke Hebrew, but by the end of 1950 , only $60 \%$ did so ${ }^{1}$.

The changes in native Hebrew accelerated in the latter half of the second and throughout the third of Morag's three periods. This can be attributed not only to the influence of the large numbers of immigrants but also to some internal developments, and is in line with what was happening in other languages at the same time. Harshav (1990) explained that during the second period, Hebrew became the foundation of society in all walks of life, and during the third period, beginning with Israel's establishment, Hebrew became the language of a country responsible for the linguistic foundation of all its institutions and systems.

\section{How the Academy of the Hebrew Language Creates New Words}

The first institution responsible for the revival of Hebrew was the Hebrew Language Committee, established in 1890, followed in 1953 by the Academy of the Hebrew Language. The Hebrew Academy continued the Committee's mission and practices based on the same methodology, which is described by Bahat (1987) and Bar-Asher (1996). Bahat enumerates eight methods - four of which we relate to here:

1. To use a root that already exists in one of the conjugations or patterns, e.g., "tahbir" (syntax) and "tahbura" (transport) from the existing root $h b " r$ (to join, to connect).

2. The "Pines method"2 of reviving ancient and obsolete words by assigning them a new meaning, e.g., ekdah (handgun), totah (cannon), margema (mortar).

These two methods are different ways of drawing from inside the language, or as Bar Asher put it, "yesh miyesh" (creating an entity from another entity).

3. Importing foreign words - a strategy which has resulted in the proliferation of prefixes and suffixes in Hebrew morphology ${ }^{3}$. Bar-Asher terms this principle "lexical importation" from foreign languages.

4. Blends — creating a new word by combining two existing words, e.g., madhom (thermometer) from mad (meter) and hom (fever).

Bar-Asher does not mention the fourth method, but instead presents the third method employed by Ben-Yehuda: "Yesh me'ayin" (creating something from nothing), by which he means the coining of new roots

\footnotetext{
${ }^{1}$ Eldar (2009, p. 540) presented data collected in a 1916-1918 population survey, indicating that $40 \%$ of participating Israeli Jews used Hebrew as their primary language, while the other 60\% used 104 other languages for oral communication (predominantly Yiddish and Arabic). The most telling evidence from this survey is that toward the end of Turkish rule, for the majority (75\%) of young Israelis in the settlements and in Tel Aviv, Hebrew was the primary language.

${ }^{2}$ Yehiel Michal Pines, who was one of the founders of the Hebrew Language Committee and also renewed a small number of words in Hebrew.

${ }^{3}$ For salient examples, see Schwartzwald (2001, p. 273), who argues that along with the non-concatenative derivation, which has been a prevalent rule in all registers of Hebrew, including Modern Hebrew, linear formation has become more and more frequent in lexical innovation.
} 
that do not exist in the language as a way of creating neologisms. This method appears in Bahat's list at nos. 5 and 8 (Bahat, 1987). Ben-Yehuda asserted that the typical Hebrew three-consonant root enables the creation of new roots by changing the order of the letters. Bar-Asher notes that this method is prevalent in Modern Hebrew, in which four-consonant roots are created from three-consonant roots, as in tfk" $d$ from $p k$ " $d$; new roots from non-Hebrew words, such as $t l p " n$ from telephone, and roots from notarikons (acronym) such as doh from din vehešbon and other derivatives (ledaveah, medaveah, etc.).

In our opinion, three of the ways presented above are accepted naturally among Hebrew speakers after 70 years of Israel's existence as a sovereign state, but the question is why a living and vibrant Hebrew needs to revive ancient words. Nowadays, Hebrew is developing easily, and new words are often born spontaneously and naturally, but while the Hebrew Academy continues to renew words, and according to Nir (2004), about $50 \%$ of them are accepted into the language, the chances that ancient words will be accepted are lower. In his study, Nir found that language speakers reject words that are not transparent, and it is well known that ancient words are often far from transparent, so why do the members of the Hebrew Academy risk reviving them? As we see it, this was appropriate for the period of the beginning of the revival of the spoken language, in which there was a great demand for new words, but it is not suitable for contemporary Hebrew. Moreover, it is known that some of the ancient words that were revived are borrowed words. Why add even more foreign words when their numbers are growing almost uncontrollably? Some examples: darga (rank) from Aramaic, avir (air) from Greek, and safsal (bench) from Latin.

In order to resolve this difficulty, we decided to examine the extent of the use of revival of ancient words in the 70 years of modern Israel's existence. This examination brings with it a need to shed light on other aspects of the issue: In what areas of life were more ancient words revived? What was the main linguistic layer from which the words were taken? How many of the revived words were loans? And from which language were most of them loaned? All these questions are addressed in this study; the last two necessitate some background to the phenomenon of borrowing words that has always been the norm and has increased the lexicon of the Hebrew language.

\section{Loan Words in the Hebrew Lexicon}

Yannai (1991) wrote of the need to bridge the gap between a language exposed to the influences of languages that are inherently different in character and modalities of expression, and Hebrew's thousand-year old linguistic legacy. Moreover, he believes it must do so without cutting off the language from its sources and while enabling it to meet the needs of future generations. Ben-Hayim (1953, p. 42) argued that by importing and absorbing new meanings - a process that has existed over many centuries — our language has incorporated new and regenerating content. This flexibility readied Hebrew for reinstatement as a spoken language that fulfills all the communicative needs of Israel's residents, and adapts itself to new circumstances as required. Thus, a revived language that preserves Biblical grammatical patterns and features differs from Biblical Hebrew in terms of denotations and content, just as the material circumstances and spiritual preoccupations of an ancient Jew differed from those of our contemporaries. This process, which was at a standstill while Hebrew served for written communication alone, has not yet ended: It is the decisive factor in linguistic innovation in a variety of areas. Ben-Hayim (1953, p. 81) further contended that it would be inconceivable to interfere with the natural evolution of a spoken language by prescribing a standard; a more productive approach is to cultivate the 
language in all its aspects - one of which is the lexicon, in which he suggests reviving words according to the needs and requirements of the speakers.

Avineri (1964, p. 339) maintained that from the beginning of the revival of spoken Hebrew, there have been conflicting attitudes to international words: Eliezer Ben-Yehuda and his adherents strove for the eradication of all foreign words from Modern Hebrew, but many writers sought them out. Between these two extremes, according to Avineri, our language has fortunately negotiated a middle path. He points out that foreign words are relatively common in the Talmud and Midrash, even more so than in Modern Hebrew-and a few foreign words can even be found in the Bible, e.g., pitgam (proverb-Aramaic), parbar (suburb-Persian), and psanter (piano - Greek). A similar line of argument is followed by Tur-Sinai (1928, p. 10), whose book reviews lexical borrowings in the Biblical period. He shows how foreign words were absorbed into Hebrew following historical upheavals - invasions of the Holy Land and interactions between speakers of different languages who lived side by side with the Jews. During that period, Hebrew incorporated words mainly from Akkadian, and during the Egyptian exile, also from Egyptian. Aramaic is the successor to Akkadian, which held sway at the time of Abraham, who came from Padan Aram (1928, p. 21). Its influence on Hebrew intensified when Aramaic became the official language of the Babylonian Empire and subsequently of the Persian Empire. It was the official language of great governments, whose rule spanned vast territories from India to Africa, and was also deemed "the professional language used by the experts" (1928, p. 31). Aramaic influenced Hebrew to such an extent that it became the second language of the Jews, on a par with Hebrew. Bar-Asher follows a similar line in his article (1996) dedicated to the linguist Eliezer Meir Lifschitz, who suggested that the gaps in Hebrew be supplemented first of all from Aramaic, rather than Arabic as Ben-Yehuda had proposed. Lifschitz gives several reasons for this: First, in the past, Aramaic influences on Hebrew evolved naturally, and the two became sister languages. Second, from the outset, Aramaic was lexically and pragmatically close to Hebrew. Third, the borrowing of Aramaic words was not an artifice, but occurred in a gradual process that spanned an entire historical epoch. And finally but crucially, Aramaic and Hebrew words are so linguistically proximal that to a Hebrew speaker they do not even feel foreign ${ }^{4}$.

\section{Stratified Modern Hebrew}

Rubinstein (2010) estimated the number of lexical entries from all Hebrew registers that are listed in all Hebrew dictionaries at approximately 45,000, including loanwords, and the number of loanwords found in the Modern Hebrew literature period to date at about two thousand.

In what follows, we present findings of three linguists who conducted lexical research on Hebrew materials encompassing the lexicon and texts from different periods. Sivan (1982) collected all lexical innovations from the time of the first immigration wave during Turkish rule up to the First World War, including words that were revived or adapted to the needs of the time. The lists he compiled include the name of the innovator but not the etymology of the word. Sarfatti (1991) analyzed the lexicon of Modern Hebrew in a corpus of spoken or close-to-spoken language after transcription, journalistic and academic language, and found it to contain a majority of words from the Bible and the Mishna. He writes that spoken language contains

\footnotetext{
${ }^{4}$ Or (2016, p. 224) described discussions that took place in the Hebrew Language Committee regarding the question: From which language would it be more appropriate to borrow features and elements-Aramaic or Arabic? Opinions differed, and while many were in favor of Aramaic, apprehensions were voiced that the very close affinity of Aramaic to Hebrew presented a threat to the purity of the latter.
} 
more Biblical words, in contrast to academic language, which contains more medieval Hebrew derivations. Moreover, new elements are scarce in spoken Hebrew, but are more prevalent in journalistic language and theoretical language ${ }^{5}$. Sarfatti also says that there are more Biblical words in spoken and journalistic language than in academic language.

The third researcher, Schwartzwald (1995), checked the number of words in the Hebrew lexicon across all historical periods. She cites the following results:

- Biblical period: $22 \%$

- Sages (Mishnaic period): $21 \%$

- Middle Ages: $17 \%$

- Lexical innovations [revived words]: $40 \%$

However, when she investigated consecutive texts in Modern Hebrew across all historical periods, based on Even-Shoshan (1970, p. 3062, as cited in Schwartzwald, 1995), the picture that emerged was altogether different:

- Biblical period: $65 \%$

- Sages: $16 \%$

- Middle Ages: 5\%

- Lexical innovations: $14 \%$

To account for these disparities, Schwartzwald explains that many of the Biblical words passed into the Language of the Sages and then to the later periods. She contends that the words revived in Modern Hebrew filled a gap but do not constitute a substantive portion of the lexicon, nor are they a distinguishing feature of Modern Hebrew. Modern Hebrew, she concludes, comprises words from all periods, and is also influenced by other languages, spoken by Jews and non-Jews alike. These and other studies have dealt with different periods of Modern Hebrew. In fact, all of the studies dealt with Modern Hebrew, but no research has hitherto been devoted to the 70 years since the establishment of the State. Furthermore, in the studies described above and other related researches, all the words were examined: Sivan checked a certain time period; Sarfatti and Schwartzwald studied all the words in a specific corpus; and Schwartzwald also investigated all lexical entries across all registers. The latter two researchers established the etymology of the words based on the period in which the word is first attested in Hebrew. Yet, no research has so far checked the ancient words that were not in continuous use across successive historical periods, and were revived or were given a new meaning during the existence of Israel as an independent State.

\section{Method}

The present research encompasses all headwords that are nouns in the latest (2003) edition of the Even-Shoshan Hebrew Dictionary. A list was compiled of all ancient words that were not in continuous use over successive periods of time, and which in Modern Hebrew has either retained their old denotation or received a new one ${ }^{6}$.

\footnotetext{
${ }^{5}$ Nir (1989, p. 10) likewise revealed a link between genres and registers, on the one hand, and lexical borrowings, on the other. He contends that in fiction and poetry, borrowings are scarce, while in journalistic reports, commentary, and advertising, they are more common. He points out that apart from the actual need for a particular word, lexical borrowings fulfill a socio-psychological function, namely, keeping abreast with the global world in general and its various trends and fads.

${ }^{6}$ Only words from classical Hebrew which ceased to be used in spoken Hebrew were chosen, or words from the Middle Ages that were not used in Modern Hebrew until the establishment of the State.
} 
To complete the picture until 2018, the study reviewed 42 issues of Academ, a newsletter published by the Hebrew Academy between 2003 and 2018. After identification, the relevant words were checked in the Gur Dictionary, published in 1946, to ascertain that the modern meanings did not yet exist. The extent of current usage was gauged using general knowledge and Google searches. Although the historical dictionary of the Ben-Yehuda project is more comprehensive and accurate than other dictionaries, it is not organized as a conventional dictionary; instead, a given word is entered and the result is citations from all written sources throughout the ages. (The Ben-Yehuda project is not yet complete, and the results do not yet include all Modern Hebrew literature). Furthermore, it gives only the meanings arising from those texts, whereas conventional dictionaries also give meanings that are not taken from texts but are standard in the spoken language (and therefore appear without citations). Nevertheless, when a need arose to access more detailed sources of words, the historical dictionary was used.

\section{Methodological Problem}

The inclusion or non-inclusion of headwords in a dictionary is usually at the discretion of its lexicographers. This makes it difficult to attain maximum accuracy in research such as this. Nevertheless, the research indicates a broad swath of ancient words that have been renewed in the 70 years of modern Israel's existence. It also reflects trends in the actions of the Hebrew Academy and the influence of the public on the language.

It should be noted that the transcription reflects the original pronunciation of the ancient Hebrew.

\section{Results}

The study identified 99 ancient words with new denotations, many of them loanwords. Most of them took on a more modern but related meaning of the original word, and 10 of them were revived together with their ancient meanings, e.g., kira (stove) and karkov (cornice), gad (luck), gofan (font), mišra (syrup). It is important to emphasize that later in the discussion, when we look at the contribution of the loanwords found in the study, we mean words borrowed by Hebrew in ancient times and having an ancient denotation, and for which, after a long period of disuse, that meaning has been retained today or the words have been given a new meaning ${ }^{7}$.

\section{The Areas in Which Many Words Were Revived}

Relations between the State and citizens. 17 words: 'agra (fee), 'omna (fostering), 'asimon (token for public phones), 'arnona (land tax), guvayna (reverse-charge call), darkon (passport), hatkana (arrangement), hilut (asset forfeiture), matsa' (political platform), miškan (building with an official purpose), qayamut (sustainability), qneset (the Israeli parliament), meli’a (plenum), qalpi (ballot box), si‘a (faction), še'ilta (parliamentary question), and tsir (diplomatic representative).

Food and cooking. 11 words: kira (stove), mạ̣metset (sourdough), 'atir (rich), 'iltit (salmon), tefiḥa (souffle), šilgon (ice lolly), 'askala (grill), revixa (roux), saharon (croissant), mišra (syrup), and mat'amiya (restaurant for light food).

Army and police. 11 words: 'efod (flak jacket), bardas (hood), ḥaziz (firecracker), maḥboš (incarceration), memugan (armor-protected), seger (closure, clasp), sexem (score used to sort candidates), rexeš ${ }^{8}$ (procurement), balder (messenger), miflag (department in the police), and hoger (soldier).

\footnotetext{
7 In the interpretation of ancient and renewed words we have noted all the possible meanings.

${ }^{8}$ Rexeš as verbal noun already existed at the time of the Hagana organization, but after Israel became a sovereign state, it was adopted also in commerce and referred to goods purchased.
} 
Technology, computers, and online communication. 8 words: pigum (action to check software), pelet (computer output), sever (cyber), gofan (font), biyuš (shaming), 'atar (site), meholel (generator), and tisa (flight).

The distribution of words by period:

- Biblical Hebrew: 31

- Sages (Mishnaic) Hebrew: 44

- Medieval Hebrew: 24

\section{Findings Related to Lexical Borrowing}

In all, 39 loanwords were identified, of which one is from an assumed source and two are from an unknown source (all the loanwords comprising $40 \%$ of the total). The languages from which the words were loaned:

- Aramaic: 29

- Greek: 5

- Syriac: 1

- Latin: 1

- Italian: $1^{9}$

- Unknown: $2^{10}$

Table 1 contains 15 of the 99 words found. The remaining words can be found in the appendix (see Table A).

Table 1

Examples of Revived Words and Their Denotations in Earlier Periods and in Modern Hebrew

\begin{tabular}{lll}
\hline Word & Ancient denotation & Modern denotation \\
\hline Arnona & S: a tax collected from residents by the Romans & Land tax only \\
'atar & S: Mainly in Mishnaic Hebrew: place & Mainly in archeology: site; building site; computer site \\
Balder & S: Messenger & Postman; agent on a secret mission \\
Biqta & S: Shack; hut & Cable hut -in communications and electronics \\
Bardas & S: An item of clothing mentioned in the Mishna & A hood attached to a coat, gas mask for kids \\
Guvaina & S: Collection of debt; demand for and collection of & Reverse-charge service \\
Dibuv & M: Speech; whisper & Dubbing (superimposing another language on speech in films) \\
Dardas & S: Slipper, light shoe, rubber overshoe (galoshes) & Smurf-small blue human-like creatures wearing large \\
Darkon & B: Persian gold/silver coin & house slippers (in children's books and films) \\
Hatqana S: Installation, setup & Passport; travel document \\
hotelet & M: Placenta; the covering of a fetus & Preparing material for printing; issuing regulations or laws \\
haziz & B: A flash of lightning accompanied by thunder & Leg warmer \\
hilut & S: Diagnosis of an infection & Fire issuing from the barrel of a large firearm; firecracker \\
tibua‘ & M: Moving something here and there, drowning someone & Absolute decision; asset forfeiture; salvaging money in a \\
mahboš & M: Bandage, healing & Bird-banding (ornithology: from teva'); coining
\end{tabular}

Notes. B-Biblical Hebrew; S-Sages (Mishnaic) Hebrew; M-Medieval Hebrew.

\footnotetext{
${ }^{9}$ It is assumed that the word "bardas" derives from its place of origin in Italy.

10 The words "karkov" and "'arnona".
} 


\section{Discussion and Conclusions}

Based on the statistical analysis of Even-Shoshan, $40 \%$ of the entries in the dictionary denote lexical innovations, i.e., words that were created since the Enlightenment (Nir, 2004). Some of them were coined based on the principle of "drawing from within the language"-reviving ancient words and either keeping their original meaning or assigning a new one. The present study examined the extent to which this strategy has been used during the 70 years of Israel's independence, and identified 99 such items. This number is minimal compared to the volume of word innovations since the revival of the new literature, which is estimated in the thousands ${ }^{11}$. According to Nir (2004), the societal needs posed by changes in reality compelled the Hebrew Language Committee and other public institutions to engage in extensive lexical innovation and create terms that are not found in ancient Hebrew sources - a challenge that was subsequently addressed also by the Academy of the Hebrew Language. We have described ${ }^{12}$ the four methods by which the Hebrew Academy has coined numerous words to enrich the language, but it is important to keep in mind that the revival of ancient words is only one of these methods. Moreover, the availability of suitable words is limited, owing to the time elapsed between the classical and medieval Hebrew periods and the establishment of the State, which accounts for the relatively small number of such words out of all lexical innovations.

Most of the revived words belong to the area of the State and its citizens, in which the language of affairs of state developed rapidly in response to the needs of independence [(e.g., 'agra (toll), 'omna (fostering a child), 'asimon (public phone token)]. The second area of identified words pertains to food and cooking, which have been common to human experience all over the world from time immemorial. Most of the words in this sphere have retained their ancient denotations in so far as they designate basic foods, e.g., 'iltit (Atlantic salmon), mahmetset (sourdough). There is no reason for these words to have changed their meanings, and the same is true for the terms designating utensils that are still in use today, e.g., kira (stove), 'askala (grill). Most of the words pertaining to other areas were adopted with new denotations. This is logical, as the areas themselves had been transformed: military and police: 'efod (flak jacket), bardas (protective hood of a child's gas mask), seger (curfew), and the modern field of technology and computers, in which almost all the revived words have been given a new meaning [such as pigum (action to support a learner), pelet (computer output), sever (cyber) $]^{13}$. The exception is gofan (font), which has returned to Modern Hebrew with its ancient meaning.

Sarfatti (2001, p. 272) explained that when two societies speaking different languages come into contact, for whatever historical or cultural reasons, conditions are created in which their languages can influence each other. Sometimes the influence is unidirectional, sometimes mutual - each language gives to the other and takes from it. Usually, the linguistic encounter goes hand-in-hand with cultural interactions, and if one of the cultures is richer and more developed than the other, the linguistic community of the latter imports words from the language of the former. Most of the words (44) identified in the present research originate in Mishnaic Hebrew, followed by Biblical (31) and Medieval (24) Hebrew. Furthermore, in line with Sarfatti (2001, p. 272), most of the words (75) come from two historical epochs: one, during which Hebrew was a living language but its speakers were under the occupation of powerful foreign empires with highly developed cultures, namely, Babylonian, Persian, Greek, and Roman; and the second, when Hebrew was a dead language that served the

\footnotetext{
11 See p. 160.

12 See p. 157.

13 While this word in Hebrew is formally an acronym (סב"ר), it is often seen nowadays without the speech marks.
} 
religious and communal purposes of the Jewish Diaspora. During these two epochs, extensive inter-linguistic interactions influenced both the communal life and the culture of the Jews. Moreover, during the Mishnaic and Medieval periods, these spheres of life developed extensively, giving rise to a need for terminology that did not exist in Biblical times. This is the main factor in the proliferation of lexical borrowings, reflected in the findings here: As already noted, 39 out of 99 are loanwords, mainly from Aramaic (29 words). This issue is elaborated in Tur-Sinai $\left(1928\right.$, p. 31) ${ }^{14}$, who explains that Aramaic was the official language of the regimes whose rule spanned the area from India to Africa, and was considered "the professional language of experts". In this connection, we have pointed out that the Hebrew Language Committee, and later the Academy of the Hebrew Language, preferred to do as their forebears had done, and borrowed Aramaic words when no ancient Hebrew word was found ${ }^{15}$.

When we consider the loanwords in the study (the words highlighted in the appendix), we see that some of them are relatively recent words that the Hebrew Academy has proposed in recent decades, while others were borrowed in the first decades of the sovereign state. The words of the second type were absorbed in speech when many Hebrew speakers, even the secular ones, were close to the language of the sources and enlisted in the effort to renew it. However, over the years, following social processes in Israel, such as the widening gap between religious and secular Jews and a reduction in the preponderance of Jewish studies in schools, there has been a distancing from the Jewish sources that has led to a lack of familiarity with the vocabulary of classical Hebrew. It seems that the members of the Hebrew Academy are aware of this, and have understood that unfamiliar words will not be accepted. They have therefore turned to the revival of ancient words only when they are transparent. In our experience as Hebrew speakers, ancient words that have been revived in the last 30 years, such as tsantar, šeliva, seger ${ }^{16}$, are indeed transparent, and Hebrew speakers have been quick to absorb them.

\section{Summary}

The study shows that in the 70 years since the establishment of the State of Israel in 1948, 99 ancient words have been revived. Forty-four of these are from Medieval Hebrew (also known as the Era of the Sages), in which there was a great deal of contact between the Jews and the cultures of the peoples under whose rule they lived. The most prominent area for revived words is state-citizen relations followed by cooking - a universal, military and police, areas that are characteristic of a sovereign state. The other areas are technology, computers, and online communication, in which the rapid emergence of technology in this period demanded a lexical response.

Why did the members of Hebrew Academy risk reviving old words that are usually unfamiliar to Hebrew speakers? The answer is revealed if the 70 years of the State's existence are divided into two: In roughly the first half of this period, when the proximity of the language speakers to the source language was greater, ancient words were revived even when they were not transparent. In the second half, this trend continued only when the words were more transparent - an essential condition for their absorption in the language. The last finding showed that 39 of the 99 ancient words that were revived were borrowed-29 of them from Aramaic, the language that most influenced Hebrew. Another question was why foreign words are added to the Hebrew

\footnotetext{
14 See p. 159.

15 Ibid.

${ }^{16}$ See the appendix.
} 
language at a time when their numbers are growing almost uncontrollably, and the answer is that these foreign words had already been absorbed into the Hebrew language and have become an integral part of it ${ }^{17}$.

We have seen that of the thousands of words renewed in the language since the Enlightenment, the number of ancient words is very small. This study is not based on a corpus that includes all lexical innovations since the emergence of Modern Hebrew literature approximately 270 years ago. Nevertheless, it is a reflection of the most significant period in the evolution of the Hebrew language, a period in which Israel became a sovereign state and in which the need for words that reflect the modern age has expanded greatly.

\section{References}

Avineri, Y. (1964). Yad Ha Lashon. Tel Aviv: Yizre'el Publishing.

Bahat, S. (1987). The path trodden by the Academy of the Hebrew Language when creating new words: On formulation concerns or practical formulation. Leshonenu laam, 38(9-10), 551-506.

Bar-Asher, M. (1996). "Fabrication" of words in the Hebrew Language Committee and in the Academy of the Hebrew Language. Leshonenu laam, 47, 3-18.

Bar-Asher, M. (2002). Modern Hebrew and its classical background. In S. Izrael (Ed.), Speaking Hebrew, Te uda, 18 (pp. 203-215). Tel Aviv: Tel Aviv University.

Ben-Haim, Z. (1953). An ancient language in a new reality. Leshonenu laam, 3(4-5), 3-83.

Cohen, H. (2005). The renewed Hebrew grammar and the sources from which it draws. Leshonenu laam, 49(3), 117-131.

Eldar, I. (2009). The revival of spoken Hebrew. In M. Bar-Asher and H. Cohen (Eds.), Mas'at Aharon: Linguistic studies presented to Aron Dotan (pp. 525-544). Jerusalem: The Bialik Institute.

Even-Shoshan, A. (2003). Even-Shoshan dictionary. Tel Aviv: Am Oved, Kinneret, Zmora-Bitan, Dvir, Yediot Aharonot.

Gur, Y. (1946). Hebrew dictionary. Tel Aviv: Dvir.

Harshav, B. (1990). Essay on the revival of the Hebrew language. Alpayim, 2, 9-54.

Morag, S. (1990). Modern Hebrew: Some sociolinguistic aspects. Cathedra, 56, 70-92.

Nir, R. (1989). Hebrew semantics: Communication and meaning. Volume 7. Tel Aviv: The Open University.

Nir, R. (2004). Modern Hebrew neologisms and their application by speakers of Modern Israeli Hebrew. In Y. Schlesinger and M. Muchnik (Eds.), Lamed-Leilash-Studies on the 30th Anniversary of the Israeli Association of Applied Linguistics (pp. 185-191). Tel Aviv: Tzivonim.

Or, Y. (2016). Creating a style for a generation: The beliefs and ideologies of the of the Hebrew language planners. Tel Aviv: Ov Publishing.

Rubinstein, D. (2010). How many words there are in Hebrew. Website of the Academy of the Hebrew Language. Retrieved from http://www-academy.org.il

Schwartzwald, O. (1995). The components of the Hebrew lexicon: The influence of Hebrew classical sources, Jewish languages and other foreign languages on Modern Hebrew. Hebrew Linguistics, 39, 79-90.

Schwartzwald, O. (2001). Derivation and innovations in Hebrew: Quantitative aspect. In O. (Rodrigue) Schwarzwald and R. Nir (Eds.), Sefer Ben-Zion Fischler: Studies in the Hebrew language and its teaching (pp. 265-275). Even Yehuda: Reches.

Sivan, R. (1982). The beginning of the expansion of the language in our times. Leshonenu laam, 33(1: 2), 321-322.

Sarfatti, G. B. A. (1991). Lexicon of Modern Hebrew. In M. Goshen-Gottstein, S. Morag, and S. Kogut (Eds.), Studies on Hebrew and other Semitic languages presented to Haim Rabin (pp. 311-327). Jerusalem: Academon.

Sarfatti, G. B. A. (2001). Semantic aspects of Hebrew. Jerusalem: The Academy of the Hebrew Language.

The Academy of the Hebrew Language. (2003-2018). Akadem: The newsletter of the Academy of the Hebrew Language. Issues 21-62.

Tur-Sinai, N. H. (1928). Loanwords in our language. Jerusalem: Reuven Mass.

Yanai, Y. (1991). The many achievements and the few failures in one hundred years of Planned Hebrew. Am Vasefer, 6, 10-20.

${ }^{17}$ See the end of p. 159, showing the four reasons why words were borrowed from Aramaic. 


\section{Appendix A}

Table A

List of the Revival Ancient Hebrew Words With the Revival of Israel

\begin{tabular}{|c|c|c|c|}
\hline Word & Ancient meaning & New meaning & Comments \\
\hline 'agra & salary & fee, toll & \\
\hline 'ariax & small brick & small brick & tile (Gur) \\
\hline 'arnona & $\operatorname{tax}$ & land tax & \\
\hline 'asda & barge & barge & \\
\hline 'asimon & deformed coin & metal token for public phones & \\
\hline 'askala & ramp & grill & \\
\hline 'askola & school of thought & system & \\
\hline 'asmaxta & promise without obligation from seller & written proof, reference & \\
\hline 'atar & place & Archeological dig site; website & \\
\hline 'avrex & religious scholar & yeshiva student & \\
\hline 'efod & sort of apron worn by the high priest & bullet-proof vest & \\
\hline 'iltit & type of fish & Atlantic salmon & \\
\hline baldar & messenger, postman & agent on a secret mission & \\
\hline bardas & type of fabric in Mishnah & hood, cowl, gas mask for kids & \\
\hline bikta & shack, hut, guest room & guest room & \\
\hline biyuš & causing shame & shaming & \\
\hline dardas & $\begin{array}{l}\text { slipper, light shoe rubber overshoe } \\
\text { (galoshes) }\end{array}$ & smurf (children's television) & Talmudic \\
\hline darkon & Persian coin in the Bible & passport & \\
\hline dibuv & speech, whisper & dubbing & \\
\hline diqur & puncture, stabbing & acupuncture & \\
\hline gad & Jupiter, luck, fortune & same meaning & \\
\hline gofan & font & same meaning & \\
\hline guvayna & debt collection, payment & reverse-charge service & \\
\hline hatqana & installation, setup & $\begin{array}{l}\text { preparing material for printing; setting } \\
\text { regulations and laws }\end{array}$ & \\
\hline karkov & $\begin{array}{l}\text { border, edge; cornice; rim around tool or } \\
\text { building }\end{array}$ & same meaning & Architecture \\
\hline kayamut & durability, sustainability & $\begin{array}{l}\text { ability to preserve what exists for future } \\
\text { generations }\end{array}$ & \\
\hline kevuda & luggage, baggage; belongings & same meaning & \\
\hline kira & stove & stove for cooking & \\
\hline kneset & meeting for various purposes & Israel's parliament & Beit kneset $=$ synagogue \\
\hline maḥbosh & bandage & incarceration & Military \\
\hline maḥmetset & sourdough & $\begin{array}{l}\text { tissue culture of bacteria for fermenting } \\
\text { milk }\end{array}$ & \\
\hline maslul & paved road & $\begin{array}{l}\text { paved road for travel, racing, and } \\
\text { competitions }\end{array}$ & \\
\hline matsa' & bed (of straw, leaves, rags) & same meaning + political platform & Politics \\
\hline meholel & dancer & generator & \\
\hline meli'a & entire field & plenum & \\
\hline memugan & extradited & with protection measures installed & \\
\hline merkav & seat of a rider, body (of a vehicle etc.) & fuselage & Aeronautics \\
\hline metujag & $\begin{array}{l}\text { adorned with a badge, characterization of } \\
\text { breeds }\end{array}$ & tagged & Computing \\
\hline miflag & division, department & administrative subdivision & Police \\
\hline miška' & clean water from dirt, sediment & residue & \\
\hline
\end{tabular}




\begin{tabular}{|c|c|c|c|}
\hline miškan & dwelling place, seat & building with an official purpose & \\
\hline mišra & syrup & same meaning in cooking & \\
\hline mitslol & diving & sound quality & Music \\
\hline mitsua' & average calculation & $\begin{array}{l}\text { same meaning }+ \text { move to the middle of } \\
\text { the text }\end{array}$ & \\
\hline nativ & road & lane on a highway & \\
\hline nehiya & transmission and guidance & guidance of blind person by a dog & \\
\hline nehuštan & copper snake & $\begin{array}{l}\text { Apharitis cilissa, a copper-colored } \\
\text { butterfly }\end{array}$ & \\
\hline nemoša & weakling, (slang) & weak in character & \\
\hline neteq & a skin lesions mentioned in the Bible & fuse disconnection & Electricity \\
\hline 'omna & growth and care & fostering (a child) & \\
\hline pelet & escape & output & Computing \\
\hline phat & reduction in quantity and value & same meaning & \\
\hline pigum & $\begin{array}{l}\text { temporary structure that serves as a } \\
\text { platform for builders }\end{array}$ & $\begin{array}{l}\text { same }+ \text { action to check software }+ \text { means } \\
\text { to support a learner }\end{array}$ & Computing \\
\hline qav & $\begin{array}{l}\text { wire, border, drawing between two points } \\
\text { (geometry) }\end{array}$ & $\begin{array}{l}\text { same meanings + cable, strategy, bus } \\
\text { route, guideline, characteristic }\end{array}$ & \\
\hline qeta $^{6}$ & $\begin{array}{l}\text { section, part; term in engineering, part of } \\
\text { a military zone }\end{array}$ & $\begin{array}{l}\text { (slang) "riot" } \\
\text { noteworthy event (slang) }\end{array}$ & \\
\hline qalpi & ballot box & same meaning for election & \\
\hline qayit & summer & summer vacation & Holiday town \\
\hline redid & scarf, shawl & shawl & \\
\hline refida & bedding, insole; lining & stratus (cloud) & \\
\hline revixa & sauce made of flour and oil & same meaning & \\
\hline rexesh & horse or donkey for riding & purchase of arms + goods purchased & \\
\hline saharon & jewel in the shape of a moon or a part of it & croissant & \\
\hline sappahat & skin disease & psoriasis & \\
\hline seger & device for closing something & $\begin{array}{l}\text { curfew, closure }+ \text { device for closing upper } \\
\text { and lower jaw }\end{array}$ & \\
\hline sever & facial expression & cyber & \\
\hline sexem & amount & score system used for sorting candidates & Only in the IDF \\
\hline $\operatorname{si}^{6} \mathbf{a}$ & group, gang & faction & Politics \\
\hline suga & fence, hedge & genre & \\
\hline še'ilta & question in Halachic discussions & parliamentary question & \\
\hline šelif & long sack for placing a load on a beast & removable note for a game & Slang \\
\hline šeliva & step & combination & \\
\hline šetel & seedling & graft, implant & Medicine \\
\hline šezer & braid, weave, bundle & to arrange, to interlace & \\
\hline šilgon & snowfall & popsicle, ice lolly & \\
\hline šimua ‘ & announcement & hearing & Law \\
\hline šizra & spine & rachis & \\
\hline šniyut & duplication & duality, dichotomy & \\
\hline tefiḥa & puffiness, swelling & same + soufflé & \\
\hline tešer & present & tip & \\
\hline tibua' & drowning someone & banding & Ornithology \\
\hline tisa & flying & flight & \\
\hline to'am & harmony, symmetry & matching, reciprocity & \\
\hline tsantar & thin pipe for oil & catheter & \\
\hline tsir & messenger, angel & same + consul & \\
\hline tsiyun & gravestone & grave & Religious language \\
\hline
\end{tabular}




\begin{tabular}{|c|c|c|c|}
\hline ya'ats & advise, provide consultation & $\begin{array}{l}\text { same meaning } \\
\text { the phrase reference book }\end{array}$ & Librarian ship \\
\hline ḥatsran & janitor, caretaker; (medieval) courtier & housefather & \\
\hline ḥavruta & friendship, learning companion & regular study partner in a yeshiva & Religious language \\
\hline ḥaziz & $\begin{array}{l}\text { a flash of lightning accompanied by } \\
\text { thunder }\end{array}$ & firecracker & \\
\hline heqer & investigation & same meaning & Education \\
\hline hemet & leather bag for liquids & $\begin{array}{l}\text { water-carrying bag with a tube and a } \\
\text { mouthpiece }\end{array}$ & \\
\hline ḥilut & diagnosis of an infection & asset forfeiture & \\
\hline ḥoger & armored with war tools & low-ranking soldier & Military \\
\hline ḥotelet & placenta & leg-warmer & \\
\hline ḥufša & freedom, no master & vacation & \\
\hline 'afuts & $\begin{array}{l}\text { materials produced from gall-nut } \\
\text { processing }\end{array}$ & sleepy & Slang \\
\hline 'atir & rich & abundant & \\
\hline 'inug & pleasure, delight, satisfaction & entertainment, enjoyment & \\
\hline 'itsum & the middle of & same + sanction & \\
\hline
\end{tabular}

Notes. The bold words are loanwords. The list is arranged in the order of the English alphabet, therefore words beginning with the guttural consonants: $\mathbf{h}$ and ' appear at the end of the appendix. 